\title{
Criticism Towards Surveillance Society and Power in Turgay Nar's Theatre Plays
}

\author{
Nurullah Ulutaş ${ }^{1}$ \\ ${ }^{1}$ The University of Mus Alparslan,
}

\begin{abstract}
Humanbeing has been striving for seizing power and objectifying other humans throughout the history. Powers, who never hesitate using any violence and punishment methods to create a disciplined society and to protect their own authority, found that surveillance is more effective than punishment by the end of the 18 th century and the beginning of the 19th century and started to discipline societies in this way. Foucault refers to a dystopia called "Panopticon" and states that powers are giant towers that observe society. Believing to be constantly observed, societies get objectified through a horror culture. Invisible powers sometimes make their presence visible through symbols like ideology, media and police. In these "control societies" as defined by Deleuze, a human type obeying to or gets objectified by authority comes to forefront rather than individual freedom.

As a prominent and unique author of Turkish literature, Turgay Nar fictionalizes plays within the scope of social and political criticism through metaphors, symbolic expressions, insecurity, mythological elements, fairy tale heroes. He makes audience watch plays with a critical approach, but also preserves the idea of Brecht who suggests that theatre should also educate audience. In his plays titled Tepegöz (Cylops), Çöplük (Trash), Şehrazat'in Oyunu (Scheherazade's Game), Can Ateşinde Kanatlar (Mevlana) (Wings Made of Spirit FireMevlana), Gizler Çarşısı (Mall of Secrets) and Hitit Güneşi (Hittite Sun), the author treats the tragedy of humanbeing objectified by power. Holding of authority by one person summarized as "Idolized Person" by Althusser and psychic life of power can be found in his artworks. He expresses even the most complex social and philosophical concepts by frequently applying to grotesque elements in a lyrical poetry through unique metaphors and symbols. In this sense, his plays require a different experience and very special prereading to be comprehended. Turgay Nar is a unique author attracting attention in Turkish theatre and brings a different dimension to theatre. Nar's plays recently attract attention of the world theatre as well. The inclusion of the play titled Şehrazat'in Oyunu (Scheherazade's Game) in 2017-2018 program Theater Augsburg in Germany will help the author, whose plays were previously exhibited in Balkans and Caucasia, open to Europe.

This study aims to analyze critical approach towards despotic power concept through surveillance society in Turgay Nar's plays.
\end{abstract}

Keywords: Turgay Nar, Authority, Panopticon, Surveillance Society, Power, Theatre.

\section{Introduction}

Man's fight for power over his own species used to rely on physical power in early periods, yet psychological intimidation and technologic surveillance have recently been predominant factors to feed this power. After adopting a sedentary life style, man has developed some rules to ensure a certain order and surveillance. Initially using physical power with the effect of primitivism, powers punished those who disobeyed the rules through killing, injuring and expelling. In following centuries, he learned both how to discipline society through prisons and to show the solid proof for the end of offenders. The French word "surveillance" is used exactly in English language referring to closely monitor the actions of a person (Clarke, 2005: 9). Although the word bears a negative meaning at the first glance, there are some positive evaluations towards the word as a positive and good concept (Martin, 1998: 64). Surveillance was used to follow traditional and religious rules (e.g. marriage and adultery) particularly in the 15th century, but nevertheless it started to be used for family planning and poor relief afterwards. Surveillance, which used to serve to the improvement of economy with the advancing capitalism at the beginning, found a legitimate ground with the concern of security following the rise 
of modern states and police departments in following centuries (Marx, 1975: 358-360 and Marx, 2005). The concepts of disciplinary and regulatory power came to the forefront with the effect of industrialization in the 18th century. This scope of surveillance called bio-politics by Foucault consists of a series of mechanisms, which turn fundamental biologic features of humanbeing into the object of politics. Disciplinary power detects a norm through an ideal behaviour model and tries to adapt individuals into the norm. The security-centred regulatory power, on the other hand, starts with measuring normality and draws a curvature of normality; accordingly adopts an attitude to this end (Foucault, 1992; Gambetti, 2009; Karakayac1 and Kurtarır, 2006).

Hobbes believes that man is a bad creature in nature and full of a never-ending desire for power. Therefore, he puts forth that individuals need to be disciplined and held under the order of a powerful authority in order to ensure social welfare and peace; thus a state is needed to this end (Hobbes, 1995: 76). He considers developing a control mechanism as a rightful act to ensure security within the scope of both state authority and social power Foucault materializes this disciplinary power ensured by surveillance in modern societies through the panopticon metaphor of Bentham. Jeremy Bentham designs an industrial building that can be applied to schools, mental hospitals, poors' house, hospitals and particularly prisons at the end of the 18th century. The design is a circular structure consisting of a surveillance tower in the center. The cell, to place each prisoner/patient/poor/student in, will be organized as a circle around the central tower. Each cell is to have two windows, one of which sees the tower while the other receives sunlight outside and gets illuminated. In this way, each cell will be constantly seen, lighted and monitored by the central tower (Foucault, 2000) so that the monitored ones will pay attention to their actions considering that they are constantly monitored. In a sense, monitoring activity will be carried out by the society itself.

In our day, computers, mobile phones, tablets and internet networks carry society, all its units and personalities to a virtual world. In the new era, it was assumed that "anarchist" characteristics of modern human presented in the fields of access to information and communication would lead to a liberal environment. (Dolgun, 2004: 55-57). George Orwell carries this topic, which is frequently treated in his novels, to theatre plays as well. In his novel titled Nineteen Eighty Four, individuals have no importance other than a number for the power in a dystopia world. The power leads people to believe its lies through screens that everyone is obliged to watch all the time. Society sustains the policies of the Party through the constantly watched screens and, in a sense, consolidates its power. (Orwell, 2010).

Turgay Nar, he comes to the forefront with his plays having particularly social and political criticism features in Modern Turkish Theatre, emphasizes surveillance society through various reference in many of his plays. The author does not hesitate bringing social and political criticism in his plays and bring problems that can be encountered in almost every society as of the early times of mankind to the stage instead of daily and vicious critics. Historical and mythological events have references to modern human tragedy on stage. Empowering his symbolic and lyric style with mythological events, the author prefers addressing to a special audience with his plays requiring a pre-reading activity. In this sense, he raises the awareness of his reader/audience as Bertolt Brecht does.

The plays in subject of this study, Nar criticizes modern administration systems taking stand from mythology and historical events. According to him, daily life dynamics transform in line with the rapidly advancing technology and current structure of the society called as "information society" gradually turns into a "surveillance society".

\section{Surveillance Tower and Blinding Policy: Can Ateşinde Kanatlar (Mevlânâ) (Transl.Wings on the Fire of Spirit-(Mevlânâ)).}

In his play titled Can Ateşinde Kanatlar (Mevlânâ) (Transl.Wings on the Fire of Spirit-(Mevlânâ)) (Nar, 2006), Turgay Nar merges symbolic characters of different times and cultures in different places. On the seventh act where Hittite Blind Sculptor tells Mevlânâ about the structure of Hittite Sun, the author metaphorically 
emphasizes how surveillance society and powers achieve disidentification of people by blinding and enslaving them.

Turgay Nar creates an impression of transferring this original story he had fictionalized through a tablet on the audience and the reader; he creates the impression of reality of the story. In this sense, his plays are full of traps. He also questions the relationship between the Power and People by using such a character. The Sun Course also refers to a cultural heritage that is passes down to generations. The Sculptor, who has lost his eyes but does not give up the struggle and at least preserves his mission to inform future generations, protects his "intellectual" identity.

\section{The Rise of Despotism and The Power of Art: Hittite Sun}

It can be seen that Turgay Nar adopts a criticism towards power over the speeches of the main character, the Sculptor and Sausga as of the first act of Hitit Güneşi, which he wrote to express the power's suppressing on the people. Just at the beginning of the play, Sausga mentions that King Suppiluliuma get a tower built to monitor his people:

It is a fact that almost all oppressive powers, from primitive societies to our day, need to monitor public. In the end, it is hard to be in power. It requires anticipating actions and taking countermeasures. For this reason, almost all the oppressive powers often use surveillance for their own future. As a matter of fact, it should be considered normal to preserve and sustain the power as it is one of the instinctive behaviours of human beings (Karakehya, 2016: 189). This is actually what the author wants to emphasize in the play. Even if Foucault is the one who carried the concept of Surveillance Tower/Panopticon to the literature, his ideas are based on a prison project designed by Jeremy Bentham. Bentham's project designed in 1791 was a method that people could not think of until that era. In this project, it was aimed to rehabilitate the bodies and minds by and to make them internalize the power (Foucault, 2006). It is not possible to observe the surveillant in this method although the one who is watching at the tower was obvious in previous methods. Staples calls this case "constant visibility". According to him, methodological, technological and non-obvious surveillance by someone is the main element of social control (Staples, 1997: 130). According to Bauman, the Panopticon model is based on power asymmetry. Bentham's great design Panopticon and "the theories symbolically represented by it are regarded as the first institutions that have widely applied surveillance asymmetry as "normal" power technology in society (Bauman, 2003, p. 59-61). King Suplililuma, one of the main characters of the play, is the person who has appeared in almost all civilizations, especially Assyria, until the establishment of the modern states, and represents the power alone gathering all the authorities in his presence. The King is the whole of power: power is for him solely (Foucault, 2012: 118).

King Suppiluliuma, in a conversation with the Goddess Sausga, asks the people not to know why he wants to build the tower: "Surveillance leads to surveillance ... People should not know that this is a surveillance tower..." (p.14), upon these words of the kind Sausga tells that the people already know the fact. In the play, the people who have to work in the construction of the tower, have a commitment to the king. This commitment is perhaps a commitment to their existence. No subject can exist without such a commitment. But again, no subject has the capacity to "see" it completely in the process of formation. In their unconscious daily life, people just accept the most painful suffering. The traumatic repetition of what is left out of daily life continues to threaten "I". The desire of people, who later get objectified as a nature of their position, for the survival is a will that can be commonly exploited by almost all the powers. As a prerequisite of being a subject, subalternity refers to being in the compulsory process of submission. Being a slave, rather than non-existence, allows them to obey it (Butler, 2005: 15). People who are afraid of forgetting the sun want ask the Sculptor to make a "sun sculpture". Though not initially accepting this idea, the Sculptor, who was later convinced, attempts to make a short chisel. The sculpture in a short period of time.

Late in the play, King Suppiluliuma is infected with the plague, his wife's labour pain starts and the tower is about to be completed. The officer, who entered the room of King Suppiluliuma being on his sickbed, tells that 
one of the workers of the tower killed another worker. It turns out that the deceased worker was the son of the king who was put among the people under the disguise of a worker in order to gather information and monitor the workers. In the final act, the wife of the king gives birth to a bat. The bat flies and lands at the top of the tower. As the people drowned in the dark speak in despair, Sausga indicates that the sun course placed in the most remarkable point of the tower will always be a hope for them. People all work together to place the sun course. As the sculpture is placed, the tower starts to collapse. One of the people tells Sausga, who warns him not to fall under the wreckage when the tower collapses, "I am not afraid, I am not afraid anymore! And he replies; "Everything, everything was about pulling off a single stone. " Sausga, who wanders among the debris, finds the heart of the sculptor hanging on the walls of the tower. The bloody bat lands over the sun watching people. Sausga kisses the heart and turns angrily towards the bat: "Your birth was from the cursed tower of the bloody power; But your death will be from the heart of an artist " and he throws the heart of the sculptor to the bat (p. 44). In this final act, Turgay Nar tries to explain that even the most autocratic dictatorships are doomed to be defeated by the creativity of the artists through the artist-power conflict. (Nar, 1997\&2006).

\section{The Surveillant Power and A Labyrinth to Atrocity: Gizler Çarşısı (Transl. Mall of Secrets)}

Turgay Nar's play titled Gizler Çarşısı (Nar, 2010); narrates how individuals are systematically monitored and acquire the imposed identity. This play is one the plays in which the modern grotesque narration is used to exemplify the creation of the loss of physical level in humans by means of violence, intimidating and recording. As the play underscores the transformation of a person into objects, the fascinating narrative style within the transformation of space, time, and event change functionalizes the probability dynamics by increasing the horror effect of grotesque "(Aycil, 2010: 9-10). In Gizler Çarşısl, Cradle Maker is a quiet and inoffensive citizen is included in a project by a torture theoretical Dr. F. and his team representing the power. According to the project, the Dwarf's mum who is the labyrinth warden of the doctor orders a special cradle. The Cradle Maker, who considers making of this special cradle made of two boys' skeletons and the nails from a snake's ribs as a prerequisite of his existence, acquires such an identity that he does not hesitate to kill his own child. When he understands the whole plan, he is on the edge of insanity and becomes the identity collector and new warden of the labyrinth by killing the Dwarf who is dragging him into this plan. We initially encounter the part of the play related to the surveillance in the act when the Cradle Maker visits the Bibliopole to get the notebook of the recipe read.

The surveillance powers are those that control people all the time to check whether the system is functioning in the way that they want, and whether people continue to have their commitment to the power. Those, who try not to depend on these powers, try to materialize their own free thoughts, and spread it to other individuals, are excluded and brought to the position of "other" by the power and those who obey the power. The oppression of being the "other" ensures the obedience of these individuals to the surveillant power even by force. In this sense, the surveillance power asks for the adoption and implementation of totalisation in one direction in the country. Such powers can be described as Totalitarian. Totalitarianism is used for the integrity between the state, ideology, political party, leadership phenomenon, which consistently regulates society as a whole, and total control system which considers society as a whole and wants to transform it as a whole as well. Totalitarianism is a political order built on the basis of imperativeness against liberalism and autonomy against freedom (Kamenka, 1992: 630).

In fact, Turgay Nar narrates how totalitarian / autocratic systems transform individuals by means of Dr. F. In the play, Dr. F. is a very modern dressed scientist having aesthetic and artistic concerns, seemingly very polite and intellectual. However, he does not see any problem in producing his products with the skin of young girls or children's bodies. The author refers to Faust implicitly through this character. In this chapter, the author tries to show that civilization cannot stop man's savagery. Representing the system, Dr. F. is someone who monitors individuals in every sense. The century we live in is a century when individuals are recorded in every sense. 
When the Cradle Maker asks the Dwarf about an explanation of what's been going on, he replies: "All these things were a kind of a work... How should I put this? Imagine it as a sort of experiment. Pre-study of the program initiated by Doctor. Yes, it is an ordinary experiment for Doctor. He has been working on a new method of interrogation for quite some time. He has made constant observations on common subconscious codes and social reflexes. He is trying to detect the mass anatomy of especially emotions, reactions and even virtues. As a result, he will have new data and new torture techniques "(p. 87).

At the end of the play, it is too late for the Cradle Maker who understands that everything is a fiction and he got objectified. Now, he has lost his family, his child, his work, his self, his feelings, his craft, his hopes and everything he has got... He takes his revenge by killing the Dwarf who leads him to this way. In fact, the power has already sacrificed the Dwarf and his mother. This is a conscious end. The author wants to express that the power uses someone in every period in this way and when the given task is completed, the power either kills or exclude these people. The power that uses violence kills its object. The power that destroyed its object incompletely attempts to suicide (Yalçınkaya, 2005: 19). Otherwise, when an individual stands up against the system, the alienation that s/he will experience will otherize her/him as well and in the end, s/he will get into a compulsory transformation (Honey, 2014: 128). It is a known fact that it is very difficult to obtain an identity in modern society and to protect it with ethical concerns (Bauman, 2010: 16-17).

After killing the Dwarf, the Cradle Maker takes over his profession and becomes the new guide of Dr. F.'s labyrinth. In this play, the narration of the author in the light of metaphors and theories in parts related to the laboratory of Dr. F. reminds us of the "eye" indicator also called as "Eye of the Power" described and emphasized by Foucault. The character Dr. F. is used to represent the use of "giant eye" as a synonym to "controller", "surveillant", "the organ of the power" (Özdel, 2012: 25)

\section{5. "History is Nothing But a Garbage Dump": Çöplük (Transl. Garbage Dump)}

Modern city prefers destroying the diversity of human bodies to respecting it. The main theme of post-1990 plays is often the problems that urban body tries to express through urban spaces. One of the best examples of this is Turgay Nar's play Çöplük, which is about the people living in the garbage dump while earning a livelihood at the edge of the city with the appropriate means offered by the city despite the city itself. Çöplük (Nar, 1997) is fictional play shedding light on the human tragedy, through story of people living in a city dump. In the play, Haço and Aymelek are siblings and İsrafil is the son of their uncle who moved to their shanty house later. The relatives have migrated to the city together and they are trying to hold on to life while living in a dump. After a while, Haço believes that there is a snake inside Aymelek whose tummy starts to grow. He puts milk in front of the so-called milk and tries to pull it out by hitting his sister in the stomach with sticks. Aymelek, who cannot stand the suffering, confesses that İsrafil raped her and she got pregnant. Hacho kills İsrafil who disappeared with an axe that he found in the well of a church. This is the well, in which they took the heads of two men that they had killed together.

The play tells us a person's adventure of decay in the process of urbanization in general; and the power within the dump itself in specific. In an evaluation regarding the play, Zehra İpşiroğlu states that rottenness of today's society is narrated over three people trying to survive in a dump. In the play, the dump is actually the symbol of life in a sense. Each and everyone is fighting to exist. Both pathetic and humorous way of war of existence begins as "conflict and battle between eternal and finite, immortal and mortal" over characters and objects (Anday, 1984, 83). Even at the beginning of the play, while Haço and İsrafil are talking to each other, they mention that the power of the dump is held by Triggerman İdris and his men:

In Çöplük, the dump which is the waste of civilization and power can be regarded as carnivalesque. Because the waste of dump replaces the stool of carnivalesque at this point. Dumps are the places of stool, dead fetus, plastic sex dolls and other countless stinking, smashed, fragmented objects and organism (Ünlüayc1l, 2003, 81). "Waste", which refers to an "end" for the urbanized, refers to a "beginning" for the those living in the dump and these people attach sacred meanings to the word. The circular time of the play Çöplük is ensured in this way 
(Ulutaş \& Ulu, 2015: 41-56). Definition and adjectives are not fixed in this play; concepts defined as "bad" differ by people who undertake these definitions. There is no pure good or pure bad in the play in which "garbage dump" reflects a second world of facts and gets shaped by the struggle of mankind for the existence. Of course, existence is spatial not only with its material aspect, but also with the spiritual aspect, thus, it is the main factor influencing the place, societies and individuals (Çetindoğan, 2009, 138). There is a hierarchy in the dump, and this hierarchy is determined by Trigger İdris. He is a person who gets along well with the ruling politicians, collects votes for them, and holds the power of the garbage dump of the city. As seen in this act of the play, the power resorts to violence whenever necessary in every period. Even in a dump, ensuring full dominance requires a good surveillance.

From time to time, the author extends his scope of political criticism with references to the social and political problems of recent history of Turkey. It is now the police of the state that monitor people in this part of the play. The killers are afraid that the heads will be found in the well of the church. The possibility of Christians to report to the police is almost impossible due to minority status. Because they will be afraid of being accused with the crime. Because in almost every society, there is a certain group who has a say in power. This group has any means of superiority over any "otherized" group in the presence of law. The power objectifies minority, and the only guarantee it gives to this social group is survival insurance (Esgün, 1999: 3). When any crime is committed in communities, the target mass is directly those minorities. The police would search for the accused among them. İsrafil, who is aware of this in the play, has this perspective while throwing the heads into the well. The author carries the issue of minorities to the agenda while treating the mean theme. According to Ayşegül Yüksel, Çöplük is a text that turns into a contemporary moral play since it questions modern humanity's today with questions by screaming rather than lecturing audience on morality although it is embellished with the mysterious abstraction of medieval moral plays (Yüksel, 1995: 15).

\section{Conclusion}

Throughout the history of mankind, the dominance of individuals over others has been achieved through money and information although it was initially based on physical strength. Although concepts such as postmodernism, globalization or information society have been created to shed light on the main social changes of our time, the concept of monitored society points to important social processes which are caused by and influence these changes (Lyon, 2006: 17). Mankind had to take a number of precautions as a prerequisite of urbanization while leading to a sedentary life from being an agricultural and nomadic society. Marx argues that the managers who had means of manufacturing with the advancement of capitalism started to keep workers in the factories under control and discipline in order to manufacture goods at a high and efficient level. Max Weber justifies surveillance suggesting that one of the characteristics of bureaucratic governance, which he regards as a rational organization model, is "detailed registration and filing" (Weber, 1986, p. 193, Bozkurt, 2008, p. 1 cited by Tümurtürkan, 2010: 6 ). A surveillance system has been developed to prevent infrastructure problems, follow-up up foreigners', theft and murder; to regulate urban trade, urban planning; and to construct streets and squares(Foucault, 2013: 20). This surveillance meets the information recorded, stored and used when necessary. In other words, this vision-based superiority refers to truth, certainty, design, thinking, exhaustion, knowledge, sovereignty, force and power. (Dolgun, 2008: 30).

Brecht argues that theatre plays must play a role in changing the audience's feelings, thoughts and attitudes, and that they should raise awareness of people in social issues (Brecht, 1997: 23). Turgay Nar is an author who witnesses his era, acts meticulously towards the cultural values and expresses the common sufferings of the society he lives in (Topcu, 2004: 44). In his plays, he tries to reveal -the modern man's tragedy through an imaginary language. The towers, labyrinths, eye symbols that remind surveillance are actually the symbols that shed light to our day. He tries to explain what sort of an impasse today's civilization society is passing through through the myths that he creates or transforms. He tells the story of the man who lost his pureness with modernism and does not hesitate to use his most brutal methods and weapons to destroy his own species. 
Modern powers that make people depersonalise people through various games and plans thanks to systematic knowledge are criticized in his plays. He tries to demonstrate that the war of power continues even in a dump and how cruel man can be when he seizes power. The modern devices, which are justified by the name of system security and various different excuses, can drive humanbeing wild. In this wildness, particularly intellectuals and artists try to oppose to the atrocities of the power that establishes authority over the other.

\section{References}

[1] Anday, Melih Cevdet. (1984). Gelişen Komedya. İstanbul: Adam Yayınları.

[2] Aycıl, Nil Ünlü. (Nar, 2010). "Bedensel Düzey Yitimi ve Şiddetten Doğan Grotesk”, Gizler Çarşlsı (Giriş Yazısı), İstanbul: Mitos Boyut Yayınları, s. 9-10.

[3] Bal, Mustafa. (2014). “Tiyatroya Doğan İmge ya da Turgay Nar'ın ‘Çöplük'ünde Şiir”. Hürriyet Gösteri Sanat Edebiyat Dergisi, Nisan, May1s, Haziran 2014, Say1: 312.

[4] Bauman, Zygmunt. (2003). Yasa Koyucular ile Yorumcular, (çev. Kemal Atakay), İstanbul: Metis Yayınları.

[5] Bauman, Zygmunt. (2010). Etiğin Tüketiciler Dünyasında Bir Şansı Var Mı?, (Çev. Funda Çoban ve İnci Katırc1), 1. bs., Ankara: De Ki Yayınları.

[6] Brecht, Bertolt. (1997). Sanat Üzerine Yazılar. (Çev; Kamuran Şipal). İstanbul: Cem Yayınları.

[7] Butler, Judith. (2005). Ikktidarın Psişik Yaşamı (Tabiyet Üzerine Teoriler). İstanbul: Ayrıntı Yayınları.

[8] Canetti, Elias. (2012). Kitle ve İktidar. (Çeviren: Gülşen Aygen). İstanbul: Ayrıntı Yayınları.

[9] Clarke, Roger. (2005), “ Have We Learnt to Love Big Brother?”. Issues (Australian National University). June 2005. Vol.71, 9-12. < http://classicbackissues.issuesmagazine.com.au/issues2005/bi71.php> at 21/06/2017.

[10] Çetindoğan Öztürk, Müşerref. (2009)."Kırsal Mitten Kentsel Ritüele Geçiş ve Beden-Mekân İlişkisinin 1990 Sonrası Türk Oyun Yazarlığına Yansıması". Tiyatro Araşstırmaları Dergisi. S.27, 2009, s.137-159.

[11] Deleuze, Gilles. (1992). "Postscript on the societies of control", October 59, Winter 1992: 3-7. (Erişim Tarihi: 20/06/2017).

(http://www.jstor.org/stable/778828?seq=1\#page_scan_tab_contents.deleuze.).

[12] Demir, Fethi. (2016). 1980 Sonrası Türk Tiyatro Edebiyatı, İstanbul: Mitos -Boyut Yayınları, s.260.

[13] Dolgun, Uğur. (2008). Şeffaf Hapishane Gözetim Toplumu. İstanbul: Ötüken Yayınevi.

[14] Dolgun, Uğur. (2004). “Gözetim Toplumunun Yükselişi: Enformasyon Toplumundan Gözetim Toplumuna”. Yönetim Bilimleri Dergisi (Journal of Administration Sciences). (1: 3) Cilt: 2, No: 2, 2004, s. 55.

[15] Esgün, İ. Uğur. (1999)."Makro İktidar, Mikro İktidar ve Hukuk”, Birikim Dergisi, İktidar ve Hukuk, Sayı, 118, Şubat 1999, s. 3

[16] Ferda Keskin. (1996).“Foucault’da Şiddet ve İktidar”, Cogito, Kış-Bahar, Sayı:6, 1996, s. 117.

[17] Foucault, Michel. (2000). Hapishanenin Doğuşu, Çev. Mehmet Ali Kılıçbay, Ankara: İmge Yayınları.

[18] Foucault, Michel. (2002), Toplumu Savunmak Gerekir, (Şehsuvar Aktaş), İstanbul: Yapı Kredi Yayınları.

[19] Foucault, Michel. (2012). Bilme İstenci Üzerine Dersler (College de France Dersleri 1970-1971). (Çeviren Kerem Eksen). İstanbul: İstanbul Bilgi Üniversitesi Yayınları, s. 118.

[20] Foucault, Michel. (2013). Güvenlik, Toprak, Nüfus 1977-1978. İstanbul: İstanbul Bilgi Üniversitesi Yayınları, s. 20.

[21] Furedi, Frank. (2001). Korku Kültürü (Risk Almamanın Riskleri). (Çeviren: Barış Yıldırım). İstanbul: Ayrıntı Yayınları.

[22] Gambetti, Zeynep. (2009). “Iktidarın Dönüşen Çehresi: Neo-Liberalizm, Şiddet ve Kurumsal Siyasetin Tasfiyesi”. I.Ü. Siyasal Bilgiler Fakültesi Dergisi, 40, 1-11.

[23] Halpern, Ben. (1961). "Myth" and "Ideology" in "Modem Usage", History and Theory, Volume: 1-5. (1960-1961), page: 129-149.

[24] Hobbes, Thomas. (1995). Leviathan. (Çev. Semih Lim). İstanbul: Yapı Kredi Yayınları.

[25] Kamenka, Eugene. (1992). "Totaliterianizm" A Companion to Contemporary Political Philosophy. Chicester /United Kingdom: John Wiley and Sons Ltd. 629,630. 
[26] Karakayacı, Ö. \& Kurtarır, E. (2006). Töre Seçilmişler ve Diğerleri, Güç, Erk, İktidar Olguları Bağlamında İnsancıl Bir İktidara Doğru. Planlama Felsefesi. (Editör: E. Kurtarır). İstanbul: Yıldız Teknik Üniversitesi Yayınları.

[27] Karakehya, Hakan\& Usluadam Kamer, Asena. (2016). "Neden Gözetleniyoruz". Anadolu Üniversitesi Hukuk Fakültesi Dergisi, Sayı: 3, s. 190.

[28] Lévi-Strauss, Claude. (1968), Structural Anthropology, Londra: The Penguin Press.

[29] Lévi-Strauss, Claude. Yaban Düşünce (The Savage Mind). (çev. Tahsin Yücel), İstanbul, Hürriyet Vakfı Yayınları, 1984.

[30] Lyon, David. (2006). Gözetlenen Toplum Günlük Hayatı Kontrol Etmek. (Çev.Gözde Soykan), İstanbul: Kalkadeon Yayınları.

[31] Martin, Brian (1998). Information Liberation Challenging the Corruptions of Information Power, London: Freedom Press.

[32] Marx, Gary T. (2005). "Seeing Hazily (but not Darkly) Through the Lens: Some Recent Empirical Studies of Surveillance Technologies".. Law and Social Inquiry. Vol 30, Issue 2, 339. https://doi.org/10.1111/j.1747-4469.2005.tb01016.x

[33] Marx, Karl (1975). Kapital (I. Cilt). Ankara: Sol Yayıları.

[34] Merquior, J. G. (1986). Foucault, (Çev. Nurettin Elhüseyni), İstanbul: Afa Yayınları.

[35] Nar, Turgay. (1997). Toplu Oyunları (Çöplük,Şehrazat'ın Oyunu, Kuyu, Terzi Makası) İstanbul: Mitos Boyut Yayınları.

[36] Nar, Turgay. (2006). Can Ateşinde Kanatlar (Mevlânâ). İstanbul: Mitos - Boyut Yayınları.

[37] Nar, Turgay. (2006). Can Ateşinde Kanatlar(Mevlânâ). İstanbul: Mitos Boyut Yayınları.

[38] Nar, Turgay. (2010). Gizler Çarşısı, İstanbul: Mitos Boyut Yayınları.

[39] Nar, Turgay. (1997\&2006). Hitit Güneşi, Broşür Yazısı.

[40] Nar, Turgay. Hitit Güneşi (Basılmamış Metin). Hitit Güneşi ilk sahnelenişi: Akademi İstanbul, Yön.: Ahmet Levendoğlu (1997), İkinci Sahnelenişi: Bursa Devlet Tiyatrosu, Yön.: Zafer Kayaokay (2006)

[41] Newman, S., (2006), Bakunin'den Lacan'a. (Çev: Kürşad Kızıltuğ), İstanbul: Ayrıntı Yayınları.

[42] Orwell, George. (2010). Bin Dokuz Yüz Seksen Dört. (Çeviren: Celal Üster). İstanbul: Can Yayınları.

[43] Özçetin, Deniz \& Özçetin, Burak. (2015/3). "Polis ve Sosyal Medya: Türkiye'de İl Emniyet Müdürlüklerinin Twitter Kullanımı”. Folklor / Edebiyat, Cilt: 21, Sayı. 83, s. 22.

[44] Özdel, Gizem. (2012). "Foucault Bağlamında İktidarın Görümezliği ve Panoptikon' ile İktidarın Gözü’ Göstergeleri”. The Turkish Online Journal of Design, Art and Communication - TOJDAC. January, Volume: 2, Issue: 1, s. 25.

[45] Russell, Bertrand, İktidar, (1990). Çev. Mete Ergin, İstanbul: Cem Yayınları.

[46] Staples, William G. (1997). The Culture of Surveillance: Discipline and Social Control in The United States. New York: St. Martin's Press. p.130

[47] Topcu, Ömer Naci. (2006). "Turgay Nar ve Can Ateşinde Kanatlar”, Can Ateşinde Kanatlar(Mevlânâ), İstanbul: Mitos Boyut Yayınları, s.16-17.

[48] Topcu. Ömer Naci. (2004). Turgay Nar'ın Can Ateşinde Kanatlar İsimli Oyununun Dramaturgi ve Reji Çalı̧̧ması. Yayımlanmamış Yüksek Lisans Tezi, Selçuk Üniversitesi Sosyal Bilimler Enstitüsü Sahne Sanatları Ana Bilim Dalı Rejisörlük Bilim Dalı, Konya.

[49] Touraine, Alain, (2002). Modernliğin Eleştirisi, Çev., Hülya Tufan, İstanbul: Yapı Kredi Yayınları.

[50] Tümurtürkan, Meral. (2010). "Gündelik Hayatın Gözetimi: Panoptikon Toplumu" [Surveillance Of Daily Life: "Panopticon Society"]", ETHOS: Felsefe ve Toplumsal Bilimlerde Diyaloglar. Sayı: 3 (2) Temmuz 2010, s. 6.

[51] Ulutaş, N.\& Ulu, E. (2015). "Turgay Nar'ın Çöplük Oyunu Üzerine Görsel İmajlar Yoluyla Bir Okuma", JASSS (International Journal of Social Science, ISSN: 2148-4163, Doi number:http://dx.doi.org/10.9761/JASSS3077 Number: 39, p. 41-56, Autumn III, 2015.

https://doi.org/10.9761/JASSS3077

[52] Ünlüaycıl, Nilay. (2003). “Grotesk Anlatım ve Türk Oyun Yazarlı̆̆ında Kullanımı”. A.Ü, D.T.C.F, Tiyatro Araştırma Dergisi, Ankara, 2003, s.68-84. 
[53] Walker, M. (1972), The National Front. London: Fontana Publish.

[54] Yalçınkaya, Ayhan. (2005). Pas (Foucault'dan Agamben'e Stvllaşmış İktidar ve Gelenek). İstanbul: Phoenix Yayınları. 